\title{
Growth of Alfavaca-Cravo in Response to Different Levels of Shade and Tiririca Density
}

\author{
Patricia Aparecida de Carvalho ${ }^{1,2}$, Maria Juliana A. de Oliveira ${ }^{1}$, Rafaela Aparecida A. de Almeida ${ }^{1}$ \\ Silvério de Paiva Freitas ${ }^{1} \&$ Geraldo de Amaral Gravina ${ }^{1}$ \\ ${ }^{1}$ Departamento de Fitotecnia, Universidade Estadual do Norte Fluminense Darcy Ribeiro, Campos dos \\ Goytacazes, RJ, Brazil \\ ${ }^{2}$ Departamento de Agronomia, Universidade Federal de Viçosa, Viçosa, MG, Brazil \\ Correspondence: Patricia Aparecida de Carvalho, Departamento de Agronomia, Universidade Federal de Viçosa, \\ Avenida Professor Padre Antônio Mendes, Estiva, 36550-000, Coimbra, MG, Brazil. Tel: 032-999-305-605. \\ E-mail: patricia.a.carvalho@ufv.br
}

Received: April 20, 2021

Accepted: May 22, $2021 \quad$ Online Published: June 15, 2021

doi:10.5539/jas.v13n7p55

URL: https://doi.org/10.5539/jas.v13n7p55

\begin{abstract}
The species Ocimum gratissimum L. is widely utilized in food, cosmetics, and folk medicine, and is also an important source of essential oils. Understanding its behavior in response to environmental conditions is of paramount importance to improving crop management methods. In this context, the following study aimed to evaluate the effects of shade, and of competition with weeds (Cyperus rotundus L.), on the growth of Ocimum gratissimum $L$. The experimental design adopted was randomized blocks, in a $5 \times 5$ factorial scheme, with 5 levels of shading $(48 \%, 75 \%, 77 \%, 83 \%$ and $90 \%)$ and 5 densities of Cyperus rotundus L. (0, 5, 10, 15 and 20 per pot), with 4 repetitions. The variables analyzed were main stem height (MSH), diameter of stem base (DSB), number of leaves on the principal branch (NL), number of ramifications (NR), chlorophyll index of leaves (CIL), foliar area (FA), dry mass of the aerial part of the medicinal species (DMAPm), dry mass of the aerial part of the weed species (DMAPw) and essential oil content (EOC). The results demonstrate that the Ocimum gratissimum L. plants presented compatible tolerance responses to up to $70 \%$ shading, and that competition with Cyperus rotundus L. was detrimental in a density above 13 plants per pot in interaction with shading. The highest dry mass production and, consequently, the highest oil yield, were obtained from the $48 \%$ shading treatment.
\end{abstract}

Keywords: competition, Cyperus rotundus L., Ocimum gratissimum L., solar radiation

\section{Introduction}

The species Ocimum gratissimum L., commonly known as clove basil, African basil, or wild basil, is an aromatic subshrub native to Asia and Africa, and is subspontaneous in all Brazilian territory. It contains numerous compounds, primarily eugenol, that are likely responsible for its antimicrobial activity (Oliveira et al., 2016). When aiming to improve crop management, it is necessary to understand its behavior in response to environmental conditions.

Secondary metabolites' regulatory mechanisms depend greatly on the genetic control inherent to each species, and on the external stimuli promoted by the environment, such as climatic and agronomic factors Environmental factors such as temperature, relative humidity, radiation, photoperiod and cultural practices influence the content and composition of essential oil in plants. Light, as a primary energy source for photosynthesis and morphogenetic phenomena, is a major factor in plant growth and development, which are further affected by the intensity, direction, duration, and quality of the light (Corrêa et al., 2012).

Similarly, competing with another species for light and other resources will activate a plant's defense mechanisms, thus altering the secondary metabolism. One such response is increasing allelochemical production and releasing them into the environment, which then affects the sensitive recipient plant's growth and development (Shah et al., 2016).

Nut grass (Cyperus rotundus L.) is a perennial weed plant species that is difficult to manage, and damages a variety of commercial crops year-round. Due to its wide adaptability to many agricultural environments, and its capacity for both sexual and asexual reproduction, nut grass is one of the top 10 weed species globally causing the most loss 
in the agricultural sector. This harm is directly caused by the competition for water and nutrients. Water availability influences all plant physiological processes, and therefore, water stress influences the allelochemical production (Rockenbach et al., 2018).

Currently, the majority of Brazilian medicinal plant studies are aimed at identifying their essential oil components. However, the crop's management is determinant to achieving both higher dry matter production rates and active ingredients of economic and pharmacological interest (Souza et al., 2014). Thus, this study's objective was to evaluate different shading levels' effects, in association with different Cyperus rotundus L. densities, on the growth of Ocimum gratissimum L.

\section{Material and Methods}

The Ocimum gratissimum L. seedlings were produced from the seeds of adult plants from the municipality of Campos dos Goytacazes-RJ. Exsiccate from the Ocimum gratissimum L. was deposited in the Darcy Ribeiro herbarium of the Universidade Estadual do Norte Fluminense (UENF), in Campos dos Goytacazes, under registration HUENF 10457.

The transplant to the $5.5 \mathrm{~L}$ capacity pot was performed 90 days after sowing. For greater yield of biomass and standardization of seedlings of Ocimum gratissimum L., flowering cuts were made, following the recommendations of Costa et al. (2007). Simultaneously, seedlings of Cyperus rotundus L. were harvested at UENF and standardized at approximately five centimeters in height.

The substrate used was composed of soil + sand + bovine manure, in a 1:1:1 proportion (v/v). The substrate's chemical characteristics were: $\mathrm{pH}$ in water $=6.0 ; \mathrm{P}$ and $\mathrm{K}\left(\mathrm{mg} / \mathrm{dm}^{3}\right)=38.0$ and $4.0 ; \mathrm{Ca}, \mathrm{Mg}$ and $\mathrm{H}+\mathrm{Al}\left(\mathrm{mmol} / \mathrm{dm}^{3}\right)$ $=36.1 ; 36.0$ and 20.0 ; organic material $\left(\mathrm{mg} / \mathrm{dm}^{3}\right)=41.89$; base saturation $\mathrm{V}(\%)=85 ; \mathrm{Zn}, \mathrm{Fe}, \mathrm{Mn}, \mathrm{Cu}, \mathrm{B}$ and $\mathrm{S}$ $\left(\mathrm{mg} / \mathrm{dm}^{3}\right)=21.75 ; 89.2 ; 74.03 ; 0.43 ; 1.35$ and 11.0 .

It is important to note that while conducting the experiment, additional fertilizer was not needed, nor were pest or disease control. This was due to the soil's physical-chemical characteristics: fertile (V\% greater than 50), containing humidified organic matter, and free of toxic elements.

The experimental design adopted was randomized blocks, with four repetitions in a $5 \times 5$ factorial scheme. The five levels of shading, obtained using Sombrite screens, were $48 \%, 75 \%, 77 \%, 83 \%$ and $90 \%$; and the five densities of Cyperus rotundus L. per pot were 0, 5, 10, 15 and 20 plants.

The experiment took place in a greenhouse in order to better control the experimental conditions. A portable Hygrometer-anemometer-luximeter (EMD THAL 300) was used to measure the shading levels. The quantity of light in every environment was determined on days with no clouds (average of three days with three measurements per day), at 12 noon. On these days, the average amount of light outside the greenhouse (11485 luxes) was considered to be $100 \%$ light ( $0 \%$ shading), which made it possible to estimate the levels of light intensity and shading $(48 \%, 75 \%, 77 \%, 83 \%$ and $90 \%$ ) for every treatment. In the $48 \%$ treatment, the Sombrite screens were not used, with shade provided only by the greenhouse's plastic covering. In the other treatments, the shading caused by the plastic together with the respective screen was considered.

Climatological data of temperature $\left(\mathrm{T}^{\circ}\right)$ and relative air humidity $(\mathrm{RH})$ were monitored during the experiment in two-hour intervals, using the Data Logger ${ }^{\circledR}$ device (model: RHT10, Extech brand) installed in the greenhouse. The temperature reached a maximum of $37.8^{\circ} \mathrm{C}$, an average of $26.0^{\circ} \mathrm{C}$, and a minimum of $19.4{ }^{\circ} \mathrm{C}$. The relative humidity was a maximum of $88.4 \%$, an average of $69.1 \%$, and a minimum of $38.5 \%$.

At 120 days after transplant, the following variables were evaluated: main stem height (MSH), using a measuring tape, taking the distance between the neck and the apex of the plant, in centimeters; diameter of the stem base (DSB), with the aid of a digital caliper, taking the measurement at the base of the stem, in millimeters, 1 centimeter from the ground; number of leaves on the principal branch (NL); number of ramifications (NR); chlorophyll index of leaves (CIL), obtained with the aid of a CIL chlorophyllometer, Chlorophyll Meter SPAD-502 (Minolta®), through the average of three readings, in the third pair of leaves in the median region of each plant, indicating the presence of chlorophyll in SPAD values (Soil Plant Analysis Development); foliar area (AF), using a LI-3100 area meter from the company LI-COR, where the value is obtained at the moment the sheet passes through the device's sensor, in $\mathrm{cm}^{2}$; dry mass of the aerial part of the Ocimum gratissimum L. species (DMAPm) and of the Cyperus rotundus L. plants (DMAPw), in which leaves, stems and flowers of all plants were collected separately, packaged in paper bags properly identified, placed in a forced circulation oven at $40{ }^{\circ} \mathrm{C}$ until they obtained constant weight and were later weighed on a digital scale (precision of $0.01 \mathrm{~g}$ ); essential oil content (EOC) was extracted as done by Rechner et al. (2011) in which EOC\% $=$ mass of oil $(\mathrm{g}) /$ dry material $(\mathrm{g}) \times 100$. The oil was extracted by the 
hydrodistillation method in a Clevenger device, using dry matter of every medicinal plant (leaves + stem + flowers) in $1200 \mathrm{~mL}$ of water for 2 hours and 30 minutes.

The experimental data was initially submitted to preliminary tests for diagnosis of data normality, and of homoscedasticity of experimental errors, of Shapiro-Wilk and Bartlett, respectively. Once these assumptions were met, the data was then submitted to a variance analysis, according to the factorial model. When the significance of the shading $\times$ density interaction was detected, it was then studied. As these are two quantitative factors, a response surface model was investigated to assess the joint effect of the two factors on the (quantitative) response variable. When the interaction was not significant, a simple regression model was adopted for each factor in isolation (this being significant).

The choice of the best regression models, both the response surface and simple regression, were based on some criteria such as: analysis of variance regression; significance test of each of the regression model coefficients; model determination coefficient and the distribution of residues in a dispersion diagram; in addition, the parsimony criterion was also used. Once the regression models chosen, graphs were drawn up and critical points were also determined (maximum or minimum), using the mathematical knowledge of derivatives.

\section{Results and Discussion}

The results of analyzing shading effects variance $(48 \%, 75 \%, 77 \%, 83 \%$ and $90 \%)$ and density of C. rotundus L. ( 0 , $5,10,15$ and 20 plants/pot) are presented in Table 1. It is observed that the main stem height (MSH), diameter of stem base (DSB), number of leaves (NL), number of ramifications (NR), chlorophyll index of leaves (CIL), and foliar area (FA) variables of Ocimum gratissimum L. were affected by the shade levels. There was an interaction between the shade levels and density of weed plants for the dry mass of the aerial part variable of the medicinal species (DMAPm). The weed's aerial part's dry mass (DMAPw) was influenced by the shade levels and density of weed plants, separately. However, the essential oil content (EOC) presented with no significant difference for the factors under study.

Table 1. Analysis of variance of the variables: Height (MSH) $(\mathrm{cm})$, diameter of stem base (DSB) (mm), number of leaves on the principal branch (NL), number of ramifications (NR), chlorophyll index of leaves (CIL), foliar area (FA) $\left(\mathrm{cm}^{2}\right)$, dry mass of the aerial part of the medicinal species (DMAPm) (g), essential oil content (EOC) (\%) of Ocimum gratissimum L. and dry mass of the aerial part of the Cyperus rotundus L. (DMAPw) (g) in different levels of shading $(48 \%, 75 \%, 77 \%, 83 \%$ and $90 \%)$ and weed densities $(0,5,10,15$ and 20$)$. Variation source (VS), degrees of freedom (DF), and mean square (MS)

\begin{tabular}{|c|c|c|c|c|c|c|c|c|c|c|}
\hline \multirow{2}{*}{ VS } & \multirow{2}{*}{ DF } & \multicolumn{9}{|c|}{ MS Variables } \\
\hline & & MSH & DSB & NL & NR & CIL & FA & DMAPm & DMAPw & EOC \\
\hline Block & 3 & & & & & & & & & \\
\hline Density & 4 & $125.685^{\text {ns }}$ & $3.0707^{\mathrm{ns}}$ & $30.260^{\mathrm{ns}}$ & $105.510^{\mathrm{ns}}$ & $37.804^{\mathrm{ns}}$ & $5028104^{\mathrm{ns}}$ & $447.772^{\mathrm{ns}}$ & $309.140^{* *}$ & $0.267 \mathrm{E}-03^{\mathrm{ns}}$ \\
\hline Shading & 4 & $5022.685^{* *}$ & $20.103^{* *}$ & $204.535^{* *}$ & $700.085^{* *}$ & $1085.977^{* *}$ & $0.1357 \mathrm{E}+09^{* *}$ & $4691.221^{* *}$ & $78.372 * *$ & $0.429 \mathrm{E}-02^{\mathrm{ns}}$ \\
\hline Dens. $\times$ Shad & 16 & $124.823^{\mathrm{ns}}$ & $2.692^{\mathrm{ns}}$ & $17.366^{\mathrm{ns}}$ & $85.029^{\mathrm{ns}}$ & $46.783^{\mathrm{ns}}$ & $0.108 \mathrm{E}+08^{\mathrm{ns}}$ & $431.638^{*}$ & $12.6897^{\mathrm{ns}}$ & $0.554 \mathrm{E}-02^{\mathrm{ns}}$ \\
\hline Residual & 72 & 83.059 & 1.512 & 17.362 & 68.048 & 77.715 & $0.152 \mathrm{E}+08$ & 222.261 & 10.036 & $0.402 \mathrm{E}-02^{\mathrm{ns}}$ \\
\hline CV & & 8.34 & 12.92 & 16.43 & 25.41 & 20.62 & 67.21 & 30.96 & 54.84 & 40.19 \\
\hline
\end{tabular}

Note. ${ }^{* *}=$ Significant at $1 \%$ probability level by $\mathrm{F}$ test; $*=$ Significant at $5 \%$ probability level by the $\mathrm{F}$ test ${ }^{\mathrm{ns}}=$ Not significant; $\mathrm{CV}$ : coefficient of variation (\%).

The shading provided a significant increase in the NL (Figure 1A) and CIL (Figure 1B) variables, and for NL a maximum value of 28.21 leaves was found for a shading of $90 \%$, indicating an increase of $39.52 \%$ in relation to the $48 \%$ shading, adjusting to the growing linear model. Such behavior suggests that in shading conditions, there is a need to acclimatize the plants to the environment, in order to obtain more efficient light absorption for photosynthetic processes (Martins et al., 2010).

The same was observed for the CIL variable (SPAD), in which there was a maximum value of 49.46 for the $90 \%$ shading, indicating an increase of $38.05 \%$ in relation to the $48 \%$ shading, adjusting to the growing linear model. The leaf green intensity was analyzed with CIL portable equipment, which evaluates the chlorophyll content of the plant in real time, since there is a significant correlation between the intensity of the green and the chlorophyll content in the leaf (Martuscello et al., 2009). 

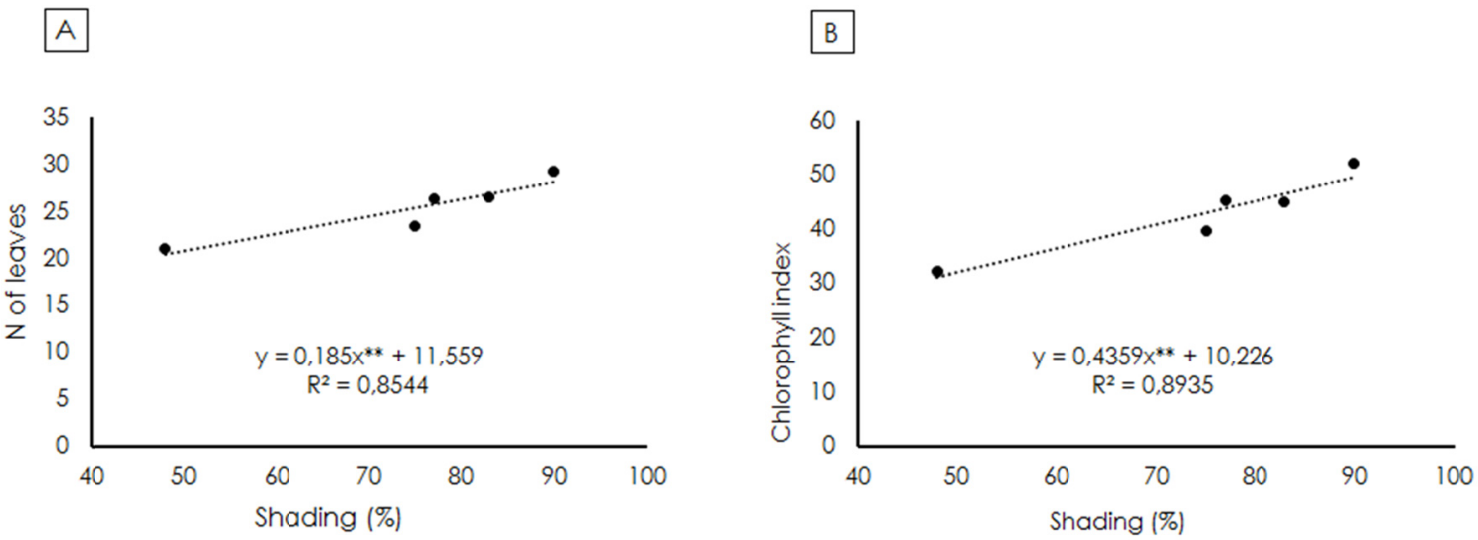

Figure 1. Influence of different levels of shading on the number of leaves on the principal branch (A) and chlorophyll index of leaves (B) of Ocimum gratissimum L.

Note. ${ }^{* *}$ Significant at the $1 \%$ probability level by the $\mathrm{F}$ test.

For the variables MSH (Figure 2A), DSB (Figure 2B), NR (Figure 2C) and FA (Figure 2D) the values were adjusted to the quadratic model, and the estimated value of MSH $(120.51 \mathrm{~cm})$ was found for the estimated shading of $73.92 \%$. Stimulating height growth is one of the most characteristic and quickest responses to shading. The ability to grow quickly when shaded is a valuable strategy to escape the most damaging changes caused by shading and can indicate a tendency to stagnation; that is, a pronounced initial investment in the vertical elongation of the stem, aimed at reaching the light more easily (Sabbi et al., 2010).

For the DSB variable, the estimated shading of $69.76 \%$ provided an estimated maximum value of $10.51 \mathrm{~mm}$. The stem's diameter is one of the best quality standard indicators, in such a way that, the larger stem diameter is associated with the more pronounced development of the aerial part and, in particular, the root system, favoring the survival and the development of the plant (Grave et al., 2007).

For the NR variable, the maximum estimated value was 40.55 branches per plant for the estimated shading of $66.24 \%$. This result is due to the plant's tolerance mechanism to shading, since plants cultivated in shaded environments have a morphology strongly focused on capturing light, and allows for better photosynthetic efficiency for greater carbon gains (Taiz \& Zeiger, 2017).

For the FA variable, it was observed that the estimated shading of $71.15 \%$ provided an estimated maximum value of $7674.33 \mathrm{~cm}^{2}$. Shading conditions provided an increase in the light interception surface on plants, as compensation for low photosynthetic rates per unit leaf area (Meira et al., 2012). 


\section{A}

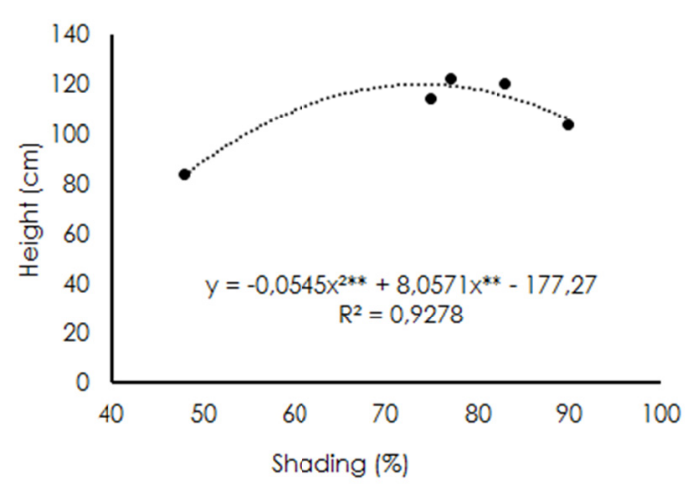

C

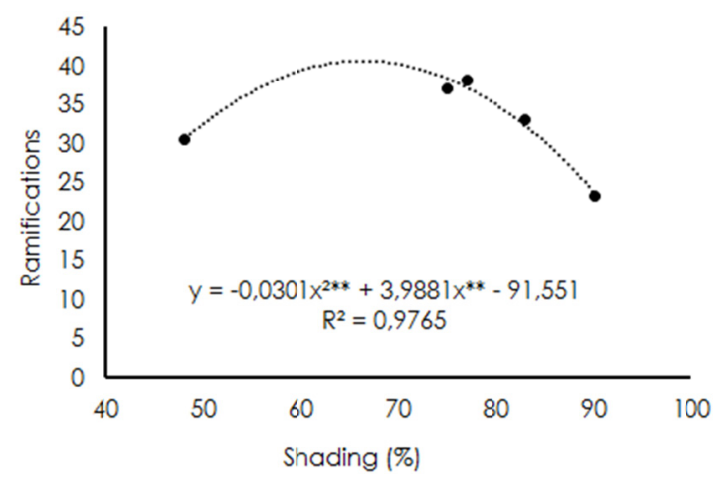

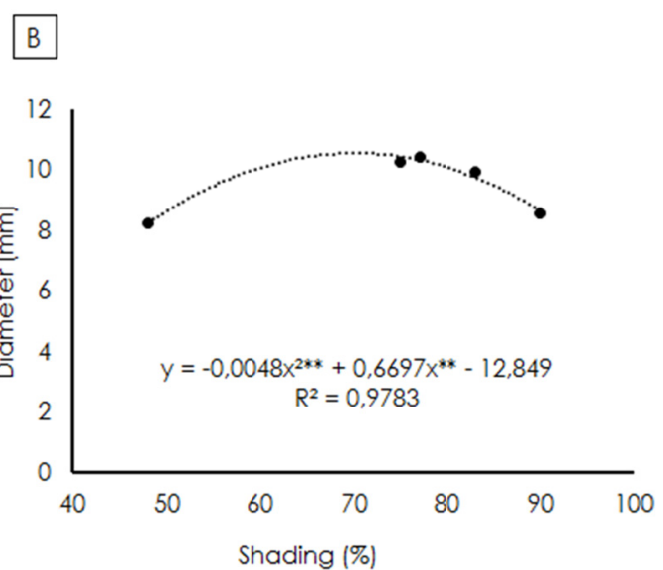
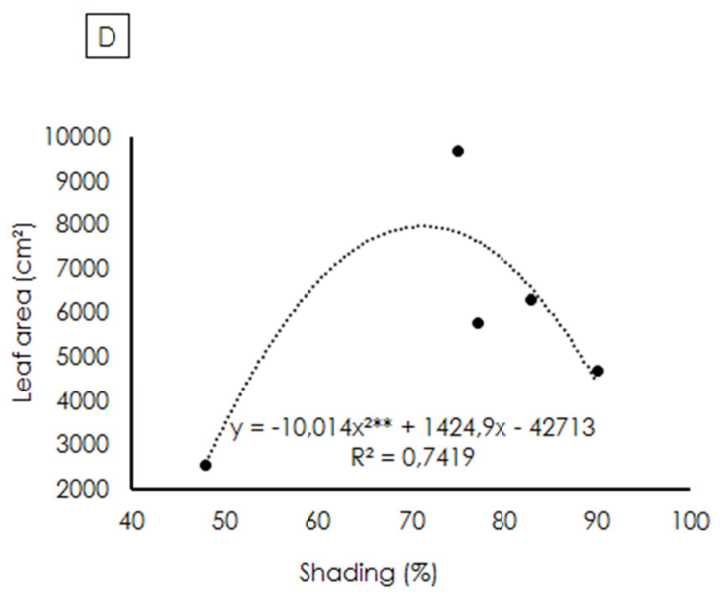

Figure 2. Influence of different levels of shading on the height (A), diameter of the stem base (B), number of ramifications (C) and leaf area (D) of Ocimum gratissimum $\mathrm{L}$.

Note. ** Significant at the $1 \%$ probability level by the $\mathrm{F}$ test.

For the DMAPw variable, the values adjusted to the decreasing linear model, having averages varying from $7.64 \mathrm{~g}$ to $3.14 \mathrm{~g}$ when the shading increased from $48 \%$ to $90 \%$ (Figure $3 \mathrm{~A}$ ), indicating a reduction of $58.90 \%$. This is due to the fact that this species is considered a $\mathrm{C} 4$ photosynthetic metabolism plant, which grows better in conditions of high temperature and intense light. However, in shading conditions, the species Cyperus rotundus L. proved not to be competitive. Despite the weed's aggressiveness, inappropriate edaphoclimatic conditions can negatively affect plant growth (Silva Terceiro et al., 2016), contributing to its management.

In addition, the DMAPw variable was further influenced by the Cyperus rotundus L. plant density, finding a maximum value of $10.84 \mathrm{~g}$ for a density of 20 plants/vase, adjusting to the growing linear model (Figure 3B). This type of behavior was already expected: Cyperus rotundus L. is an overly-aggressive weed species, with high reproducibility (sexual and asexual), easy dispersion, and rusticity. These characteristics provide the species with advantages when competing with agricultural crops, resulting in productivity loss and, consequently, losses for the farmer (Vasconcelos et al., 2012). 

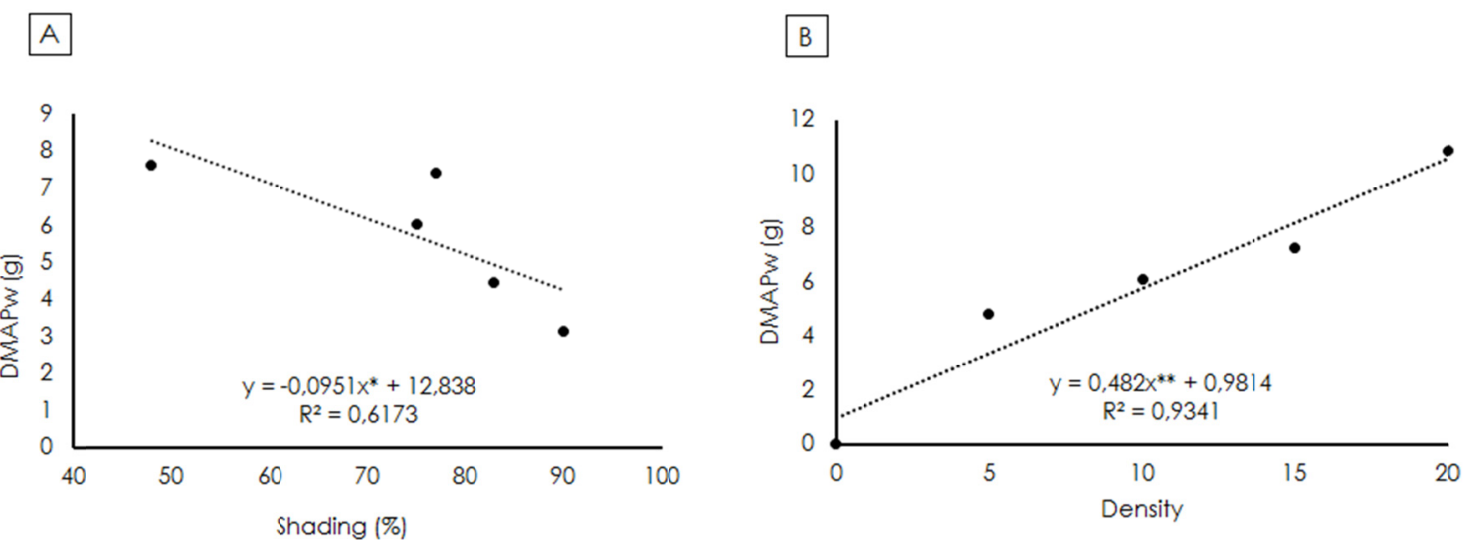

Figure 3. Influence of different levels of shading (A) and density of plants (B) on the dry mass of the aerial part of Cyperus rotundus $\mathrm{L}$.

Note. ${ }^{* *}$ Significant at the $1 \%$ probability level by the $\mathrm{F}$ test.

On the other hand, the DMAPm presented quadratic behavior with the maximum value estimated in the shading of $48 \%$ and with an estimated density of 13.34 plants of Cyperus rotundus L. per pot (Figure 4). Above 13 weeds per pot, the dry mass of Ocimum gratissimum L. was reduced. These results may be due to the weed's aggression, imposing competition with the medicinal plant for space and production resources.

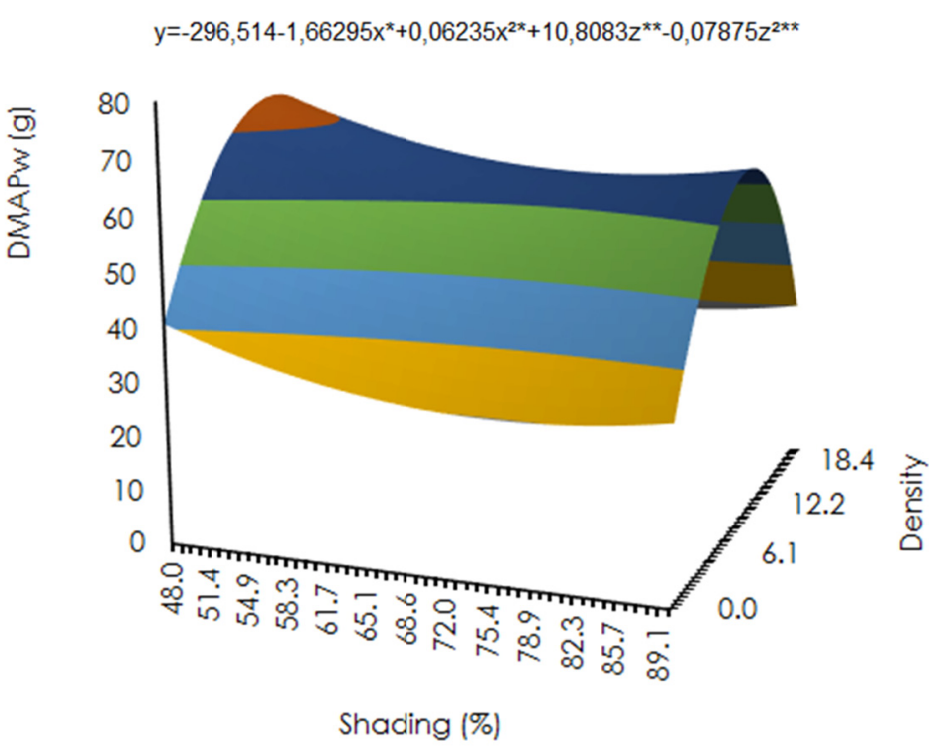

Figure 4. Influence of different levels of shading and densities of Cyperus rotundus $\mathrm{L}$. on the dry mass of the aerial part of Ocimum gratissimum L.

Note. ** Significant at the $1 \%$ probability level by the $\mathrm{F}$ test.

The EOC variable did not present significant differences due to the different levels of shading and density of Cyperus rotundus L. (Table 1). However, the plants grown with $48 \%$ shading, even with less leaf area (Figure 2D) presented similar essential oil content as the other treatments. Although this variable was not influenced by the factors studied, a condition of $48 \%$ of shading, there is greater production of dry mass of plants (Figure 4) and, therefore, greater yield of essential oil.

\section{Conclusion}

Based on the above results, it can be concluded that the phytomass in Ocimum gratissimum L. plants is affected by shade and by density of Cyperus rotundus L. Generally, the Ocimum gratissimum L. plants presented tolerance responses to shading. 
The greater production of dry mass and, consequently, the highest yield of oil, was obtained in lower shading. In contrast, competition Cyperus rotundus L. proved to be harmful in interaction with shading for the dry mass of the aerial part of the medicinal species.

\section{References}

Corrêa, R. M., Pinto, J. E. B, Reis, E. S., \& Moreira C. M. (2012). Crescimento de plantas, teor e qualidade de óleo essencial de folhas de orégano sob malhas coloridas. Global Science and Technology, 5(1), 11-22.

Costa, L. C. B., Pinto, J. E. B., Bertolucci, S. K. V., \& Cardoso, M. G. (2007). Produção de biomassa e óleo essencial de elixir-paregórico em função do corte das inflorescências e épocas de colheita. Horticultura Brasileira, 25(2), 175-179. https://doi.org/10.1590/S0102-05362007000200009

Grave, F., Franco, E. T. H., Pacheco, J. P., \& Santos, S. R. (2007). Crescimento de plantas jovens de Açoita-cavalo em quatro diferentes substratos. Ciência Florestal, 17(4), 289-298. https://doi.org/10.5902/ 198050981961

Martins, J. R., Alvarenga, A. A., Castro, E. M., Silva, A. P. O., \& Alves, E. (2010). Teores de pigmentos fotossintéticos e estrutura de cloroplastos de Alfavaca-cravo cultivadas sob malhas coloridas. Ciência Rural, 40(1), 356-363. https://doi.org/10.1590/S0103-84782010000100011

Martuscello, J. A., Jank, L., Gontijo Neto, M. M., Laura, V. A., \& Daniel Cunha, D. N. F. V. (2009). Produção de gramíneas do gênero Brachiaria sob níveis de sombreamento. Revista Brasileira de Zootecnia, 38(7), 1183-1190. https://doi.org/10.1590/S1516-35982009000700004

Meira, M. R., Martins, E. R., \& Manganotti, S. A. (2012). Crescimento, produção de fitomassa e teor de óleo essencial de melissa (Melissa officinalis L.) sob diferentes níveis de sombreamento. Revista Brasileira de Plantas Medicinais, 14(2), 352-357. https://doi.org/10.1590/S1516-05722012000200015

Oliveira, L. B. S., Batista, A. H. M., Fernandes, F. C., Sales, G. W. P., \& Nogueira, N. A. P. (2016). Atividade antifúngica e possível mecanismo de ação do óleo essencial de folhas de Ocimum gratissimum (Linn.) sobre espécies de Cândida. Revista Brasileira de Plantas Medicinais, 18(2), 511-523. https://doi.org/10.1590/ 1983-084X/15 222

Rechner, O., Neugart, S., Schreiner, M., Wu, S., \& Poehling, H. M. (2016). Different narrow-band light ranges alter plant secondary metabolism and plant defense response to aphids. Journal of Chemical Ecology, 42(10), 1-15. https://doi.org/10.1007/s10886-016-0755-2

Rockenbach, A. P., Rizzardi, M. A., Nunes, A. L., Bianchi, M. A., Caverzan, A., \& Schneider, T. (2018). Interferência entre plantas daninhas e a cultura: alterações no metabolismo secundário. Revista Brasileira de Herbicidas, 17(1), 59-70. https://doi.org/10.7824/rbh.v17i1.527

Rosal, L. F., Pinto, J. E. B. P., Bertolucci, S. K. V., Brant, R. S., Niculau, E. S., \& Alves, P. B. (2011). Produção vegetal e de óleo essencial de boldo pequeno em função de fontes de adubos orgânicos. Revista Ceres, 58(5), 670-678. https://doi.org/10.1590/S0034-737X2011000500020

Sabbi, L. B. C., Ângelo, A. C., \& Boeger, M. R. (2010). Influência da luminosidade nos aspectos morfoanatômicos e fisiológicos de folhas de Schinus terebinthifolius Raddi (Anacardiaceae) implantadas em duas áreas com diferentes graus de sucessão, nas margens do Reservatório Iraí, Paraná, Brasil. Iheringia Série Botânica, 65(2), 171-181.

Shah, A. N., Iqbal, J., Ullah, A., Yang, G., Yousaf, M., \& Fahad, S. (2016). Allelopathic potential of oil seed crops in production of crops: A review. Environmental Science and Pollution Research International, 23(15), 14854-14867. https://doi.org/10.1007/s11356-016-6969-6

Silva Terceiro, E. M., Pessôa, U. C. M., Souza, A. S., Soares Filho, A. A., \& Pimenta, T. A. (2016). Aspectos fisiológicos do feijão-caupi e crescimento de tiririca (Cyperus rotundus L.) sob competição em solo compactado. Revista Verde de Agroecologia e Desenvolvimento Sustentável, 11(1), 14-22. https://doi.org/ 10.18378/rvads.v11i1.4069

Souza, G. S., Silva, J. S., Oliveira, U. C., Santos Neto, R. B., \& Santos, A. R. (2014). Crescimento vegetative e produção de óleo essencial de plantas de alecrim cultivadas sob telas coloridas. Biosci. J., 30(1), 232-239.

Taiz, L., \& Zeiger, E. (2017). Fisiologia e desenvolvimento vegetal (6th ed., p. 858). Porto Alegre: Artmed.

Vasconcelos, M. C. C., Silva, A. F. A., \& Lima, R. S. (2012). Interferência de Plantas Daninhas sobre Plantas Cultivadas. Revista Agropecuária Científica no Semiárido, 8(1), 01-06. https://doi.org/10.30969/acsa. v8i1.159 


\section{Copyrights}

Copyright for this article is retained by the author(s), with first publication rights granted to the journal.

This is an open-access article distributed under the terms and conditions of the Creative Commons Attribution license (http://creativecommons.org/licenses/by/4.0/). 